\title{
ENHANCING THE ROLE OF FIELD EXPERIENCE SUPERVISORS: TOWARD MULTICULTURAL EQUITY IN A TEACHER PREPARATION PROGRAM
}

\author{
Lisa VASQUEZ
}

iD : https://orcid.org/0000-0001-5213-3655

Minnesota State University, Mankato, MN United States of America

The current state of education embodies increasing public demands and policy mandates for teacher accountability in all classrooms, pre-kindergarten through Grade 12. Leaders expect increased academic performance to meet grade-level curriculum standards within a multicultural society. Teacher preparation programs are tasked to create and manage field experiences that guide practice within diverse learning communities. Teacher candidates interact with the cultural, social, and historical context of schools, of professional colleagues, and of the pupils they teach. In addition, teacher candidates should be prepared to develop practices that are intentional, personalized, differentiated, and purposeful for the pupils within their classrooms. This paper offers a case study of one university's re-design of field experience supervision in its teacher preparation programs. The curriculum designers sought to ensure support for teacher candidates based on each student's individual needs, while fostering systemic change responsive to ideas of race, gender, and other areas of intersectionality in a multicultural society. The field supervisor was the key to connect the practical, field-based experiences with the vision and mission of the university. Thus, program leaders identified the need to invest in the professional development of field supervisors in a way that brought the vision and mission to life-from words to action. The resulting framework included a multi-faceted approach of coaching / mentoring, professional development, and reflective discourse with colleagues.
ARTICLE HISTORY

Received:

28 November, 2020

Accepted:

5 March, 2021

Published:

25 April, 2021

Available online:

25 April, 2021

\section{KEYWORDS}

Teacher preparation, multicultural

education,

Racial justice, diversity, field supervision 


\section{Introduction}

Since ancient times, education and its definition has been a topic of conversation, reform, politics, and research (Bruner, 1971; Dewey, 1938; Fraser, 2007; Gatto, 2001; Zeichner, 2014). A major theme of educational reform focuses on providing effective preparation so that teacher candidates can successfully navigate current multicultural educational landscapes with theory and practice (Clift \& Brady, 2005; National Council for the Accreditation of Teacher Education [NCATE], 2010; National Research Council [NRC], 2010). A variety of goals and objectives have emerged over the years. However researchers, administrators, and teachers continue to strive for effective practices to educate pupils from prekindergarten through secondary school.

The current state of education embodies increasing public demands and legislative mandates for teacher accountability at all grade levels in all classrooms, pre-kindergarten through Grade 12. One major goal is increased academic performance to meet grade-level curriculum standards within a multicultural society. Educational research often highlights school progress and ability of pupils around the world. For example, the Programme for International Student Assessment (PISA), reports data about pupils in Grade 8 throughout the world (Organisation for Economic Co-operation and Development [OECD], 2019). In 2018, approximately 600,000 students completed the assessment, statistically representing about 32 million 15 -year-olds in the schools of the 79 participating countries and economies. In the United States, 4,838 students, in 215 schools, completed the assessment, representing $3,559,04515$-year-old students (86\% of the total population of 15-year-olds). In Baku (Azerbaijan), 6,827 students, in 197 schools, completed the assessment, representing 20,271 15-year-old students (46\% of the total population of 15-year-olds). Some results for 2018 are presented in Table 1.

Table 1 Percent of 15-year-old Pupils attaining at least Level 2 proficiencies in 2018.

\begin{tabular}{|l|l|l|l|}
\hline Subject area & OECD average & Baku (Azerbaijan) & United States \\
\hline Reading & $77 \%$ & $40 \%$ & $81 \%$ \\
\hline Mathematics & $76 \%$ & $49 \%$ & $73 \%$ \\
\hline Science & $78 \%$ & $42 \%$ & $81 \%$ \\
\hline
\end{tabular}

Source: Organisation for Economic Co-operation and Development [OECD], 2019. 
At a time of persistent unemployment, economic instability, and multicultural workforce, data such as this can be used to question whether schools are adequately preparing pupils to work within the multicultural economy. Over the last two decades, a re-conceptualization of teacher-preparation programs has developed, with an emphasis on multicultural and effective field experience opportunities. This paper describes and reflects on curriculum re-design of one university's teacher preparation program in order to prepare teachers who can meet the challenges of the 21st century.

\section{The "Learning by Doing" Model}

Curriculum designers and re-designers seek to support the development and shared understanding of essential concepts such as teaching, teaching practices, learning teaching, critical thinking, as well as other skills. Teacher preparation programs were tasked to design field and practice experiences that moved away from the traditional ideals of student teaching and toward a "Learning by Doing" model (NCATE, 2010).

The "Learning by Doing" model accentuated ways to develop intentional field experiences grounded in meaningful and productive opportunities for teacher candidates to engage in purposeful teaching practices (Lampert, 2010). Currently, programs using this model, engage teacher candidates in co-constructing contextualized teaching practice with peers and more experienced practitioners. Together, they determine teaching practices to provide the most meaningful learning experiences for diverse groups of pupils, while bringing attention and deeper understanding to a particular aspect of teaching and learning. Together, they enact and assess learning experiences that have been specifically designed for particular pupils. Together, they participate in dialogue and reflection on practice. Teacher candidates learn with and from peers, expert practitioners, and the pupils they teach (Hollins, 2015).

\section{Re-designing Field Experiences in Teacher Preparation}

So, today, teacher preparation programs are tasked to create and manage field experiences that guide practice within a multicultural learning community. Teacher candidates interact with the cultural, social, and historical context of schools, of professional colleagues, and of the pupils they teach. Thus, teacher candidates must be prepared to facilitate learning and behavior within the multicultural classroom. Teacher candidates need to be ready to engage in just and equitable practices, such as conversations about privilege, race, equity, equality, and marginalization. In addition, teacher candidates should be more prepared to develop practices that are intentional, personalized, differentiated, and purposeful for the pupils within their classrooms. 
Currently, institutions that prepare teacher candidates for licensure are concerned with the facilitation and development of effective field experience components within their programs (Grossman, 2010; NCATE, 2010; National Education Association [NEA], 2014). The roles of the university faculty, content and methods instructors, field supervisors, mentor teachers, and everyone involved in the development of teacher candidates, must evolve to support effective teacher preparation.

Field experience supervision is an essential programmatic feature of teacher development (Darling-Hammond, 2014; Gimbert \& Nolan, 2003; Lee, 2011). Yet, the scholarly literature is missing research and analysis about the role, support, and development of the field supervisor (Burns \& Badiali, 2016; Grossman, 2010; Hamel \& Jaasko-Fisher, 2011; Valencia et al., 2009; Zeichner \& Bier, 2015). Consequently, while the role of the supervisor has much potential to enhance the quality of teacher preparation, building the capacity of schools and mentors to support high-quality field experiences is necessary for this role to be optimized.

\section{Method}

The Minnesota State University, Mankato's (MSUM) College of Education (COE) has developed an intentional framework to support university field supervisors in their critical role of guiding teacher candidates. This paper offers a case study of this university's re-design of the field experience supervision in its teacher preparation programs.

\section{Context and Background}

The Minnesota State Colleges and Universities system is comprised of 30 state colleges and seven state universities with 54 campuses throughout Minnesota. The university in Mankato is the largest in the entire system, with enrollment of approximately 15,000 undergraduate and graduate students. Approximately, $10 \%$ of the students are from under-represented groups, and $10 \%$ of the students are international scholars.

At this time, MSUM features six colleges with a wide variety of academic programs. The COE's primary role is to prepare professional educators, counselors, and education leaders. In addition to the core teacher preparation programs, the COE houses centers in the areas of engaged leadership, educator partnerships, and educator support as well as MSUM's aviation and military science departments. The nationallyaccredited COE has a charge to prepare students and educators to embrace a multicultural society. 
In the past, the COE faculty's role was to prepare teacher candidates from wellestablished theoretical and methodological viewpoints. The teacher preparation role provided opportunities to showcase examples of effective practices connected to the coursework, specific programs, and/or licensure. However, students anecdotally reported that the learning and discussion that occurred within campus classrooms were frequently disconnected from actual practice in the field experiences. In the past, the instructor's role in the methods course varied by grade level, intended licensure, and content area. Due to different expectations of various teacher licensures, the instructors' role was somewhat disconnected across individual programs and often resulted in inequitable field experience opportunities for teacher candidates. The field supervisor's role was to observe instruction in school classrooms, evaluate teacher candidates on the progress of their instructional practices, and provide feedback for candidate growth. These criteria were largely based on the Danielson Framework for Teaching (Danielson, 2007).

\section{Operationalizing the Vision and Mission}

Encouraged by the call for educational and pre-service teacher reform (Clift \& Brady, 2005; NCATE, 2010; NRC, 2010), MSUM's COE crafted a vision and mission that is grounded in teacher preparation with racial equity and social justice. The vision of the $\mathrm{COE}$ is "to inspire lifelong learning and professional engagement through racial consciousness, social justice, and inclusion within a global context (College of Education, 2021)." And the COE mission is "to prepare professionals through research and evidence-based practices who demonstrate excellence in their profession (College of Education [COE], 2021)." The vision and the mission of the $\mathrm{COE}$ became foundational reference points to frame classroom instruction, program requirements, professional development opportunities, and field experiences.

In 2010, MSUM became a partner with the New Teacher Center (NTC), a nonprofit organization driven by the mission to improve student learning by accelerating the effectiveness of new teachers, experienced teachers, and school leaders (New Teacher Center, 2021). NTC's model included (1) face-to-face professional development, (2) formative assessment tools, and (3) protocols to mentor and coach beginning teachers. COE curriculum leaders found that the NTC goals were in alignment with the COE vision and mission. However, at that time, field supervisors were not required to attend this training or use the formative assessment tools and protocols. 
The COE began this reframing process through the development of working definitions of several terms. Creating these definitions foreshadowed the subsequent work by engaging members of the COE, content area instructors, faculty, advisors, field supervisors and partners in professional development to examine systemic racism in courses and in field experiences. For MSUM, the current versions of the definitions are included in Table 2.

Table 2 .Definitions

\begin{tabular}{|c|c|c|}
\hline Term & Definition & Source \\
\hline $\begin{array}{l}\text { Cultural } \\
\text { competence }\end{array}$ & $\begin{array}{l}\text { An ability to learn about and interact effectively with } \\
\text { people of diverse backgrounds, experiences, and } \\
\text { perspectives. This competence comprises four } \\
\text { components: (1) awareness of one's own cultural } \\
\text { worldview, (2) attitude towards cultural differences, (3) } \\
\text { knowledge of different cultural practices and } \\
\text { worldviews, and (4) cross-cultural skills. }\end{array}$ & $\begin{array}{l}\text { Minnesota State University, } \\
\text { Mankato, 2016, p. } 33 .\end{array}$ \\
\hline $\begin{array}{l}\text { Culturally } \\
\text { responsive }\end{array}$ & $\begin{array}{l}\text { Recognizing, understanding, and applying attitudes } \\
\text { and practices that are sensitive to and appropriate for } \\
\text { people with diverse backgrounds, experiences, and } \\
\text { perspectives. }\end{array}$ & $\begin{array}{l}\text { Minnesota State University, } \\
\text { Mankato, 2016, p. } 32 .\end{array}$ \\
\hline Culture & $\begin{array}{l}\text { The way of life of a group of people; encompassing } \\
\text { their ideas, values, beliefs, norms, language, traditions, } \\
\text { and artifacts. }\end{array}$ & $\begin{array}{l}\text { Minnesota State University, } \\
\text { Mankato, 2016, p. } 32 .\end{array}$ \\
\hline Diversity & $\begin{array}{l}\text { Variety among peoples and perspectives. Differences } \\
\text { may include, but are not limited to, gender, ethnicity, } \\
\text { race, national origin, socioeconomic status, religion, } \\
\text { gender identity, gender expression, abilities/ } \\
\text { disabilities, age, physical appearance, } \\
\text { marital/partnered status, and veteran status. }\end{array}$ & $\begin{array}{l}\text { Minnesota State University, } \\
\text { Mankato, 2016, p. } 32 .\end{array}$ \\
\hline Equity & $\begin{array}{l}\text { The proportional distribution or parity of desirable } \\
\text { outcomes across groups, with the goals of being just, } \\
\text { impartial, and fair. }\end{array}$ & $\begin{array}{l}\text { Minnesota State University, } \\
\text { Mankato, 2016, p. } 32 .\end{array}$ \\
\hline Multicultural & $\begin{array}{l}\text { Refers to a collective variety of cultures that can be } \\
\text { defined along racial, sex, class, sexual orientation, } \\
\text { gender identity, gender expression, language, religious, } \\
\text { and education lines. }\end{array}$ & $\begin{array}{l}\text { Minnesota State University, } \\
\text { Mankato, 2016, p. } 33 .\end{array}$ \\
\hline
\end{tabular}

Source: Minnesota State University, Mankato, 2016.

The COE faculty and staff members began reflection on the vision, mission, and implementation of social equity and racial justice within a multicultural school population. The changing language and practices in schools revealed the need for systemic changes that would be responsive to race, gender, and other elements of 
intersectionality. Curriculum leaders realized that program practices were laced with inequities, even sustaining oppressive practices. These oppressive practices were challenging to the success of diverse teacher candidates. For example, curriculum designers recognized that COE leaders declare their intention to recruit and retain teacher candidates from diverse cultures. However, many of the actual administrative and programmatic practices disenfranchised those same teacher candidates in ways that impacted their physical, financial, and mental well-being. As faculty members in the teacher preparation programs at MSUM embraced the COE vision and mission, they became convinced of the need for all field experience supervisors to operate with racial consciousness and social justice.

\section{The Roles of Field Experience Supervisors}

Faculty members valued the field experiences, but there was a need to be more intentional to make the practice more consistent and positive for teacher candidates as learners and as future educators. The aim became to foster the development of teacher candidates with the pedagogy, beliefs and confidence to skillfully navigate and critique the educational system as they advocated for beneficial change for all pupils. In reviewing the curriculum, designers recognized the value of the current field experience model and the reliance upon the supervisor's role in supporting teacher candidates in practice.

The field supervisor was the key to connect the practical, field-based experiences with the vision and mission of the COE. Thus, program leaders identified the need to invest in the professional development of field supervisors in a way that brought the vision and mission to life-from words to action. By doing so, a culture of racial consciousness, collaboration, and equity would create an optimal learning environment for all teacher candidates in the MSUM teacher preparation programs.

\section{Strategic Practices toward Equitable Supervision}

With an increased focus on equitable field experiences, the COE's Office of Field and International Experiences (OFIE) updated the field supervisor job description to include NTC training and the use of high-leverage tools to support supervision of teacher candidates. Over time, NTC and MSUM's COE collaborated to move from a professional development model designed to support beginning teachers to a model that embraces the developmental needs and skills of teacher candidates. 
Faculty members sought to provide equitable supervision for teacher candidates so they grew in their capacities to teach with racial equity and social justice. The faculty and staff members acknowledged the essential role of the field supervisor. However, without purposeful professional development and transparent and consistent expectations of supervisors, the teacher candidates were not consistently supported through effective, equitable practices. So, the COE developed a framework for equitable supervision to support the needs of the teacher candidates. The multi-faceted approach includes coaching or mentoring, professional development, and reflective discourse.

\section{In-Field Coaching and Mentoring}

Field supervisors are coached in-field (i.e., within the schools) as they interact with a teacher candidate. The "lead coach" gathers non-evaluative evidence of the supervisor's practice and engagement with the teacher candidate. This field-based collaboration informs the teaching in the college and also offers personalized learning opportunities to support and develop the reflective practices of the supervisors. These coaching conversations focus on high-leverage processes occurring between the supervisor and the teacher candidate. This personalized approach starts where the field supervisor is in their own multicultural journey and provides the individual support needed to advance their effective practices. In-field coaching is intended to facilitate self-analysis, setting goals, building on strengths, and growing in coaching capacity. In other words, this layer of support is COE's chance to support supervisors, gather data on field experiences, and be responsive to the needs of the field supervisors. These engagements provide opportunities to see how the vision and mission of COE live in the daily experiences of the supervisor and teacher candidate.

\section{Professional Development}

Supervisors attend a four-day, in-person professional development series intended to provide strategic coaching for supervisors using protocols from Courageous Conversation about Race (Singleton, 2015), NTC formative assessment tools, procedures that support optimal learning environments for all students, and effective instructional coaching. During these sessions, foundations of effective coaching, including behavior and language, building trust, and working with adult learners are introduced, modeled, and practiced. Also introduced are tools and protocols that guide and assess teacher development within instructionally-focused coaching cycles of inquiry. 
Field supervisors now receive job-embedded professional development about supporting and modeling equitable practices. Program faculty members began engaging and collaborating in professional development training. Program leaders held seminars, workshops, self-study modules, and task force meetings in order to foster the multicultural and equity journeys of faculty members and field supervisors. Multiple opportunities are facilitated to reflect and adapt current practices, discourse, reflection, and actions. Examples of the materials used during these opportunities are displayed in Table 2.

Table 3. Resources for Critical Practices in Supervision for Teacher Preparation

\begin{tabular}{|l|l|}
\hline \multicolumn{1}{|c|}{ Resource } & \multicolumn{1}{|c|}{ Author/s } \\
\hline $\begin{array}{l}\text { Courageous Conversations } \\
\text { Rhat Does It Mean to Be White? Developing White } \\
\text { Rateracy }\end{array}$ & Singleton, 2015 \\
\hline $\begin{array}{l}\text { What Does Justice Look Like? The Struggle for Liberation } \\
\text { in Dakota Homeland }\end{array}$ & DiAngelo, 2012 \\
\hline $\begin{array}{l}\text { Pedagogy of Confidence: Inspiring high intellectual } \\
\text { performance in urban schools }\end{array}$ & Wazyiatawin, 2008 \\
\hline $\begin{array}{l}\text { Critical Race Theory: An Introduction } \\
\text { The cycle of socialization }\end{array}$ & $\begin{array}{l}\text { Delgado, Stefancic, \& } \\
\text { Harris, 2017 }\end{array}$ \\
\hline
\end{tabular}

\section{Reflective Discourse}

Another component of the MSUM's COE's teacher candidate framework provides the opportunity for supervisors to learn from one another, engage in critical reflection about teaching candidates, and be encouraged and validated within their own professional development. Within MSUM's COE, the Teacher Candidate Support Network (TCSN) is a collaboration of the Center for Educator's Support (CES), OFIE, Center for Educator Partnerships and Student Success (CEPSS), and COE faculty members.

Members of the TCSN discuss many topics, including the intentional placements of teacher candidates with supervisors and mentor teachers. Teacher candidates share opinions and connections that have an impact on programs and field experiences. Curriculum designers and field supervisors engage in 
conversations about student knowledge, growth and expectations. The TCSN provides seminars and experiences that connect the campus-based classroom studies to the field-based practical experiences, embedding Critical Race Theory (Delgado, Stefancic, \& Harris, 2017), as well as aspects of storytelling and autobiography.

TCSN meets monthly to calibrate practice and continue professional development. These meetings provide a place to analyze data. to reflect on problems of practice, and to celebrate the successes of supervisors and teacher candidates during the field experiences. Meetings are designed to provide continued skill and content building related to high-leverage coaching tools and protocols, thoughtful coaching cycles, and practice. Within these meetings, discourse occurs surrounding multicultural, equity-minded, effective practices, to support cultural relevance between supervisors and the support team within the COE.

\section{Implications for Teacher Preparation}

The language of the COE vision and mission is being brought to life through professional development and coaching. Supervisors are moving through their personal racial equity journeys as they build confidence and comfort around having conversations relating to race equity and social justice in a multicultural society. TCSN continues to provide opportunities for personal reflection and skill development.

Culturally responsive pedagogy embedded into the supervisory role helps all stakeholders to gain confidence in conversations around equity and justice. They are able to identify gaps and overlaps in the field experience itself and the teaching expectations within the classroom.

Field supervisors reflect on the language that they use with teacher candidates. Does their language align with the COE vision and mission? What implications might there be when biases or misconceptions are present? Are teacher candidates using evidence-based practices to show growth? Within this model of field supervision, supervisors are held accountable for challenging personal and systemic beliefs and habits. They are engaging in discourse around the calibration of practices, allowing each supervisor and teacher candidate the opportunity to learn and grow in their own journey of professional development. 
The framework is helping the COE bring life to the vision and mission by embracing our teacher candidates fully. The increased racial consciousness of supervisors means increased and purposeful conversations surrounding race and a more respectful and responsive support of diverse candidates. Teacher candidates consider issues of equity as they implement COE's vision and mission in rubrics, assignments, and daily instruction. Conversations surrounding race, bias, and challenging norms occur more often among faculty members, field supervisors, and teacher candidates. With this model, teacher candidates may "fail forward," allowing them to grow through challenges, discouragement and discovery.

Pupils in prekindergarten through Grade 12 continue to be at the center of the work. All the support, training, and analysis is for the best interest of the whole child. With this framework, conversations are occurring that directly impact pupil progress. The field supervisor understands the importance of environmental context and relationships that must develop before classroom instruction can effectively occur. The teacher candidate creates meaningful instruction with the classroom pupils in mind. Whenever roles can be modified, there is the possibility of systemic change to more positively impact student learning.

\section{Disclosure statement}

No potential conflict of interest was reported by the author. 


\section{References and notes:}

Bruner, J. (1971). The Relevance of Education (1st ed.). New York, NY: Norton.

Clift, R. \& Brady, P. (2005). Research on methods courses and field experiences. In M. Cochran Smith \& K. Zeichner (Eds.). Studying Teacher Education: The report of the American Educational Research Association panel on research on teacher education (pp. 309-424). New York. NY: Routledge.

College of Education. (2021). About the College of Education. Mankato, MN: Minnesota State University, Mankato. Accessed March 9, 2021 from https://ed.mnsu.edu/about-thecollege-of-education/.

Danielson, C. (2007). Enhancing Professional Practice: A framework for teaching (2nd ed.). Alexandria, VA: Association for Supervision and Curriculum Development.

Delgado, R. \& Stefancic, J., \& Harris, A. (2017). Critical Race Theory: An introduction (3rd ed.). New York, NY: New York University Press.

Dewey, J. (1938). Experience and Education. New York, NY: Touchtone.

DiAngelo, R. (2012). What Does It Mean to Be White? Developing White Racial Literacy. New York, NY: Peter Lang Publishing.

Fraser, J. (2007). Preparing America's Teachers: A History. New York, NY: Teachers College Press.

Hollins, E. (2015). Rethinking Field Experiences in Preservice Teacher Preparation: Meeting new challenges for accountability. New York, NY: Routledge.

Grossman, P. (2010). Learning to practice: The design of clinical experience in teacher preparation. [Policy brief]. Washington, DC: American Association of Colleges for Teacher Education (AACTE).

Hamel, F. \& Jaasko-Fisher, H. (2011). Hidden labor in the mentoring of pre-service teachers: Notes from a mentor teacher advisory council. Teaching and Teacher Education, 27(2), 434442. https:/ / doi.org/10.1016/j.tate.2010.09.013

Harro, B. (2018). Cycle of Socialization. In Adams, M., Blumenfeld, W. J., Catalano, D. C. J., Dejong, K., Hackman, H. W., Hopkins, L. E., Love, B., Peters, M. L., Shlasko, D., \& Zuniga, X. (Eds.) Readings for Diversity and Social Justice. (4th ed.). (pg. 45-51). New York, NY: Routledge.

Jackson, Y. (2011). Pedagogy of Confidence: Inspiring high intellectual performance in urban schools. New York, NY: Teacher's College Press.

Lampert, M. (2010). Learning teaching in, from, and for practice: What do we mean? Journal of Teacher Education, 61(1-2), 21-34. DOI: 10.1177/0022487109347321.

Minnesota State University, Mankato. (2016). Current diversity definition - accepted 2004. Strategic Diversity and Inclusion Plan 2016 - 2017. Mankato, MN: Minnesota State University, Mankato. $\quad$ Retrieved March $\quad 10, \quad 2021$ from https:// mankato.mnsu.edu/globalassets/diversity--inclusion/files/documents/20162017-strategic-diversity--inclusion-plan.pdf.

National Council for Accreditation of Teacher Education (NCATE) (2010). Transforming teacher education through clinical practice: A national strategy to prepare effective teachers. Washington, DC: National Council for Accreditation of Teacher Education.

National Research Council (NRC) (2010). Preparing teachers: Building evidence for sound policy. Washington, DC: National Academics Press.

New Teacher Center (NTC). (2021. About NTC. Retrieved March 10, 2021, from https://newteachercenter.org/about-ntc/

Organisation for Economic Co-operation and Development (OECD) (2019). Programme for International Student Assessment (PISA). Paris, France: OECD Publishing. Retrieved March 10, 2021, from https://www.oecd.org/pisa/.

Peterson, P. E., Woessmann, L., Hanushek, E. A., \& Lastra-Anadón, C. A. (2011). Globally challenged: Are U.S. students ready to compete? The latest on each state's international standing in math and reading. [PEPG Report No. 11-03] Boston, MA: Harvard Kennedy School. Retrieved

March

10 , 2021 from: 
http:/ / hanushek.stanford.edu/sites/default/files/publications/Peterson \%2BWoessm ann \%2BHanushek\%2BLastra\%202011\%20PEPG.pdf

Singleton, G. (2015). Courageous Conversations about Race: A field guide for achieving equity in schools. Thousand Oaks, CA: Corwin Press.

Valencia, S., Martin, S., Place, N., \& Grossman, P. (2009). Complex interaction in student teaching: Lost opportunities for learning. Journal of Teacher Education, 60(3), 304-322. DOI: $10.1177 \%$ 2F0022487109336543.

Waziyatawin. (2008). What Does Justice Look Like? The struggle for liberation in Dakota homeland. St. Paul, MN: Living Justice Press.

Zeichner, K. (2014). The struggle for the soul of teaching and teacher education in the USA. Journal of Education for Teaching, 40(5), 551-568. DOI: 10.1080/02607476.2014.956544.

Zeichner, K. \& Bier, M. (2015). Opportunities and pitfalls in the turn toward clinical experience in U.S. teacher education. In E. Hollins (Ed.), Rethinking Field Experiences in Preservice Teacher Preparation: Meeting new challenges for accountability. (pp. 20-46). New York, NY: Routledge. 